\title{
INVESTIGATIONS OF THE INFLUENCE OF SUFAN ON MYOCARDIAL METABOLISM IN CASES OF EXPERIMENTAL HEART FAILURE
}

\author{
Iryna Nizhenkovskaya ${ }^{1}$
}

\begin{abstract}
This article presents the results of an influence by the new non-glycoside structure, metabolic cardiotonic drug "sufan" on the energetic metabolism and oxidative homeostasis indicators-in myocardium, brain, and spleen of intact rats and rats with adriamycin-induced heart failure. It was established that sufan increased the coefficient of oxidative/reduced forms of nicotinamide coenzymes, reduced the adriamycin, causing deterioration of the energetic metabolism and the pro-oxidative-anti-oxidative homeostasis. The use of the non-glycoside structure cardiotonic drug, sufan, is recommended in order to prevent cardiotoxic effects of the anthracycline antibiotics.
\end{abstract}

UDC Classification: 547.431.4 - 547.854.4; 547.96, DOI: http://dx.doi.org/10.12955/cbup.v2.477

Keywords: sufan, adriamycin hydrochloride, heart failure, energetic metabolism

\section{Introduction}

An adverse drug reaction is the actual problem of modern pharmacotherapy. Many side effects from medication narrow the field of its use, and requires special medical care and careful control during these drugs administration (Chekman, 1980). One of such drugs is an antitumor, antibiotic adriamycin, which causes the development of cardiomyopathy that manifests itself with the occurrence of heart failure in patients (Stukov, Myronyuk, \& Konkov, 1998). The adriamycin-induced intoxication is also accompanied by severe disturbances of many cardiomyocytes enzyme systems (Saprikina \& Salnik, 1988). The cardiac glycosides administration in case of adriamycin-induced intoxication does not reduce its severity, but rather enhances the structural abnormalities in the myocardium (Nizhenkovska, Chekman, \& Pisarev, 1996). There are data concerning the attempts to reduce the adriamycin cardiotoxicity by the combined use of the cardiac glycosides with the cardioprotective medications. One of these medications is "sufan," a new non-glycoside cardiotonic drug, which acts as a cardio-protector as it relates to the succinic acid derivatives and may have certain effect on the energy metabolism of the heart muscle (Chekman, Guduvok, \& Gorchakova, 1994). Sufan effectively prevents the development of morphological disorders in the myocardium during the adriamycin-induced intoxication (Nizhenkovska et al., 1996). The aim of this investigation is to explore the possibilities of correcting energy metabolism and oxidative homeostasis disorders in the myocardium of rats, which are administered sufan during the adriamycin-induced intoxication.

\section{Methods}

The investigations were conducted on 120 Wistar male-rats, weighing between 150 and 200 g. These experimental rats were divided into 4 groups: (1) the control group; (2) those injected with only sufan (35 mg/kg); (3) those injected with only anthracycline antibiotic; (4) those injected with a combination of adriamycin and sufan. Adriamycin was administered intramuscularly (IM) once a week $(5 \mathrm{mg} / \mathrm{kg}$ ) for 5 weeks; sufan was administered daily intramuscularly also for 5 weeks. The myocardial tissue, brain, and spleen of the rats were studied. $10 \%$ homogenates were prepared in $0.05 \mathrm{M}$ Tris buffer (pH 7.4). All manipulations were carried out at the temperature of $4^{0} \mathrm{C}$. In myocardial tissue, the content of nicotinamide coenzymes (nicotinamide adenine dinucleotide oxidized form [NAD $\left.{ }^{+}\right]$and the reduced form [NADH], nicotinamide adenine dinucleotide phosphate oxidized form [NADP $\left.{ }^{+}\right]$and the reduced form [NADPH] was determined with the use of fluorometry. The activity of NAD-hydrolase was determined by the enzymatic method. The content of creatine phosphate (CP) in the myocardial homogenate was determined as a difference between total and free creatine via spectrophotometry. The activity of the creatine phosphokinase (CPK) was assessed using the photo-colorimetric method.

\footnotetext{
${ }^{1}$ Iryna Nizhenkovskaya, Bogomolets National Medical University, Kiev, Ukraine, dekan-farm@ukr.net
} 
The adenine system components were determined with the help of spectrophotometry. In the heptaneisopropanol extracts of tissue homogenates of myocardium, brain, and spleen, the content of primary products of lipid peroxidation (LPO) in the heptane and isopropanol phases, the diene conjugates (DC) $\left(E_{232} / E_{220}\right)$, was determined (Volchehorskyy, Nalimov, \& Jarovinskij, 1989). In the tissue homogenates, the content of secondary LPO products that react with 2-thiobarbituric acid (TBA-active products), mainly the malondialdehyde (MDA), was measured (Baraboj, Orel, \& Karnaukh, 1991). In the tissues of myocardium, brain, and spleen, the content of glutathione in the reduced state was determined (Prokorova, 1982). In the post-mitochondrial fractions of the same tissue, obtained by the generally used method, the activity of the glutathione cycle enzymes-glutathione reductase and glutathione peroxidase, was determined (Kruglikova \& Shtutman, 1976). The obtained data were statistically processed using the Student's criteria.

\section{Results and Discussions}

It was determined that the IM administration of sufan in intact rats, at a daily dosage of $35 \mathrm{mg} / \mathrm{kg}$ for 5 weeks, led to the reduction of the nicotinamide coenzymes in the reduced form in the myocardium by $10.5 \%$, which had a certain effect on the increase of oxidized/reduced forms coefficient $(+14.3 \%)$. This fact indicates a decrease in the degree of coenzymes reduction that can be regarded as a positive effect on the functioning of various chains of cell metabolism. In the same experimental conditions, sufan showed very little effect on the number of adenine system components and on the content of inorganic phosphate; it slightly increased the level of CP and glycogen in the myocardium (as shown in Tables 1 through 4).

The level of inorganic phosphate increased by 31\%; the level of CP decreased more than by 2 times; the CPK activity decreased by 1.7 times, showing the deterioration of the energy metabolism in myocardial tissue (see Table 1). It should also be noted that the level of glycogen in myocardium reduced to $95.2 \pm 8.0 \mathrm{mg} / \mathrm{kg}$ (see Table 1 ).

Table 1: The effect of sufan on the CP, glycogen content, and CPK activity in rats with adriamycininduced heart failure

\begin{tabular}{|c|c|c|c|}
\hline Animal group & $\mathrm{CP}, \mathrm{mmol} / \mathrm{g}$ & $\begin{array}{c}\text { CPK, mcmol CP per } 1 \mathrm{~g} \\
\text { tissue in } 1 \mathrm{~min}\end{array}$ & Glycogen, mg/kg \\
\hline $1^{\text {st }}(n=10)$ & $3.40 \pm 0.88$ & $5.75 \pm 0.22$ & $218.2 \pm 13.1$ \\
\hline $2^{\text {nd }}(n=10)$ & $4.04 \pm 0.36$ & $5.45 \pm 0.17$ & $276.3 \pm 17.9$ \\
\hline $3^{d}(n=10)$ & $1.40 \pm 0.20 *$ & $3.28 \pm 0.24 *$ & $95.2 \pm 8.0 *$ \\
\hline $4^{\text {th }}(n=10)$ & $3.20 \pm 0.44 * *$ & $4.46 \pm 0.18$ & $184.5 \pm 11.8^{* * *}$ \\
\hline
\end{tabular}

Source: Author

Notes: ${ }^{*} \mathrm{p}<0.05$ in the $1^{\text {st }}$ group (control group), ${ }^{* *} \mathrm{p}<0.05$ in the $3^{\text {rd }}$ group

The adriamycin-induced intoxication was accompanied by distinct changes in almost all studied parameters of myocardial energy metabolism: in the nicotinamide coenzymes system, the level of oxidized forms decreased by $26 \%$, and the level of total number of nicotinamide coenzymes decreased by $9 \%$ with some increase in the content of reduced forms. Consequently, the ratio of oxidized/reduced forms was reduced by $36.6 \%$; thus, the NAD-hydrolase activity increased by $37.5 \%$ (refer to Table 2). 
Table 2: The effect of sufan on the level of nicotinamide coenzymes and the NAD-hydrolase activity in myocardium of rats with adriamycin-induced intoxication

\begin{tabular}{|c|c|c|c|c|c|}
\hline $\begin{array}{l}\text { Animal } \\
\text { group }\end{array}$ & $\begin{array}{c}\mathrm{NAD}^{+}, \mathrm{NADP}^{+}, \\
\mathrm{mcmol} / \mathrm{kg}\end{array}$ & $\begin{array}{l}\text { NADH, } \\
\text { NADPH, } \\
\text { mcmol/kg }\end{array}$ & $\begin{array}{c}\text { Total number of } \\
\text { nicotinamide } \\
\text { coenzymes, } \\
\text { mcmol/kg }\end{array}$ & $\begin{array}{c}\text { Ratio of } \\
\text { oxidized/reduced } \\
\text { forms }\end{array}$ & $\begin{array}{c}\text { NAD- } \\
\text { hydrolase, } \\
\text { mcmol/kg }\end{array}$ \\
\hline $1^{\mathrm{st}}(\mathrm{n}=10)$ & $493 \pm 8$ & $345 \pm 80$ & $838 \pm 13$ & $1.43 \pm 0.04$ & $2609 \pm 27$ \\
\hline $2^{\text {nd }}(n=10)$ & $502 \pm 11$ & $297 \pm 10 *$ & $799 \pm 11$ & $1.69 \pm 0.03 *$ & $3015 \pm 42 *$ \\
\hline $3^{\mathrm{d}}(\mathrm{n}=10)$ & $365 \pm 7^{*}$ & $396 \pm 13$ & $764 \pm 7 *$ & $0.92 \pm 0.02 *$ & $3589 \pm 86^{*}$ \\
\hline $4^{\text {th }}(n=10)$ & $4430 \pm 5 * *$ & $370 \pm 12$ & $813 \pm 32$ & $1.2 \pm 0.04^{* *}$ & $3088 \pm 39 * *$ \\
\hline
\end{tabular}

Source: Author

Notes: ${ }^{*} \mathrm{p}<0.05$ in the $1^{\text {st }}$ group (control group), ${ }^{* *} \mathrm{p}<0.05$ in the $3^{\text {rd }}$ group

Under the influence of adriamycin hydrochloride, IM administered for 5 weeks, the amount and composition of adenine nucleotides were significantly changed; the level of adenosine triphosphate (ATP) decreased by 29\%; the level of adenosine diphosphate (ADP) decreased by $14 \%$, while the level of adenosine monophosphate increased by 55\%; thus, the myocardial energy potential was reduced by $20 \%$, and the ratio of ADP/ATP was increased 1.5 times (refer to Table 3).

Table 3: The effect of sufan on the adenine nucleotides content and the inorganic phosphate (Pi) in myocardium of rats with adriamycin-induced intoxication

\begin{tabular}{|c|c|c|c|c|c|}
\hline $\begin{array}{l}\text { Animal } \\
\text { group }\end{array}$ & $\begin{array}{c}\text { ATP, } \\
\mathrm{mcmol} / \mathrm{g}\end{array}$ & ADP, mcmol/g & $\begin{array}{l}\text { AMP, } \\
\mathrm{mcmol} / \mathrm{g}\end{array}$ & $\begin{array}{c}\text { ATP+ADP+AMP, } \\
\text { mcmol/g }\end{array}$ & $\mathrm{Pi}, \mathrm{mmol} / \mathrm{g}$ \\
\hline $1^{\text {st }}(n=10)$ & $2.04 \pm 0.07$ & $1.38 \pm 0.08$ & $0.89 \pm 0.06$ & $4.31 \pm 0.2$ & $85.6 \pm 6.2$ \\
\hline $2^{\text {nd }}(n=10)$ & $2.26 \pm 0.02$ & $1.42 \pm 0.13$ & $0.81 \pm 0.05$ & $4.49 \pm 0.3$ & $84.2 \pm 6.0$ \\
\hline $3^{\mathrm{d}}(\mathrm{n}=10)$ & $1.44 \pm 0.02 *$ & $1.17 \pm 0.03^{*}$ & $1.36 \pm 0.08^{*}$ & $3.97 \pm 0.3$ & $112.0 \pm 9.0^{*}$ \\
\hline $4^{\text {th }}(n=10)$ & $1.68 \pm 0.13^{*}$ & $1.64 \pm 0.12^{* *}$ & $1.02 \pm 0.05^{* *}$ & $4.34 \pm 0.4$ & $92.4 \pm 7.4$ \\
\hline
\end{tabular}

Furthermore, the use of adriamycin led to the deterioration of the pro-oxidative-anti-oxidative homeostasis in myocardium of rats (refer to Table 4). Thus, the amount of TBA-active products was increased by 3.6 times; the reduced form of glutathione was reduced by 60\%; the activity of glutathione reductase was increased by $28.9 \%$ and the activity of glutathione peroxidase was decreased by $25.7 \%$. When comparing the indices of pro-oxidative-anti-oxidative homeostasis in myocardium and in tissues with high sensitivity to toxins and hypoxia (brain and spleen), we have revealed the same changes, but they were more considerable. Thus, in brain tissue, the content of TBA-active products was increased by 16.3 times; the reduced form of glutathione was decreased by 79.5\%; the activity of glutathione reductase remained unchanged; the activity of glutathione peroxidase was decreased by $23.9 \%$. In the spleen, the content of TBA-active products was increased by 5.1 times; the reduced form of glutathione was increased by $20.7 \%$; the activity of glutathione reductase was increased by $45.3 \%$; the activity of glutathione peroxidase was unchanged (refer to Table 4). Attention must be paid to the primary products of LPO, such as DC, the amount which remained unchanged neither in heptane phase nor in isopropanol phase, in any of the studied organ. It 
is obvious that unstable DC does not accumulate in tissues, but rather converts to the end products of LPO or can be reduced with the help of antioxidant defense systems.

\begin{tabular}{|c|c|c|c|c|}
\hline $\begin{array}{l}\text { Animal } \\
\text { group }\end{array}$ & $\begin{array}{l}\text { TBA-active } \\
\text { products, } \\
\text { nmol/mg of } \\
\text { protein }\end{array}$ & $\begin{array}{l}\text { Glutathione, the } \\
\text { reduced form, } \\
\text { mg/g }\end{array}$ & $\begin{array}{c}\text { Glutathione } \\
\text { reductase, nmol } \\
\mathrm{NADPH}^{*} / \mathrm{mg} \\
\text { protein }\end{array}$ & $\begin{array}{c}\text { Glutathione } \\
\text { peroxidase, mcmol } \\
\text { glutathione/mg } \\
\text { protein per } 1 \mathrm{~h}\end{array}$ \\
\hline 1 & 2 & 3 & 4 & 5 \\
\hline \multicolumn{5}{|c|}{ Myocardium } \\
\hline $1^{\mathrm{st}}(\mathrm{n}=10)$ & $7.23 \pm 1.17$ & $0.638 \pm 0.062$ & $14.21 \pm 0.90$ & $69.12 \pm 1.83$ \\
\hline $2^{\text {nd }}(n=10)$ & $7.25 \pm 2.07$ & $0.725 \pm 0.092$ & $13.08 \pm 1.02$ & $70.52 \pm 2.94$ \\
\hline $3^{\mathrm{d}}(\mathrm{n}=10)$ & $26.19 \pm 2.56 *$ & $0.253 \pm 0.031^{*}$ & $18.32 \pm 0.61 *$ & $51.36 \pm 1.72 *$ \\
\hline $4^{\text {th }}(n=10)$ & $18.36 \pm 1.14^{* *}$ & $0.348 \pm 0.036 *$ & $18.71 \pm 0.53^{*}$ & $50.19 \pm 1.68 *$ \\
\hline \multicolumn{5}{|c|}{ Brain } \\
\hline $1^{\text {st }}(\mathrm{n}=10)$ & $8.53 \pm 1.72$ & $0.352 \pm 0.040$ & $27.35 \pm 1.45$ & $68.54 \pm 1.92$ \\
\hline $2^{\text {nd }}(n=10)$ & $8.48 \pm 1.82$ & $0.361 \pm 0.050$ & $28.03 \pm 1.68$ & $67.38 \pm 1.36$ \\
\hline 1 & 2 & 3 & 4 & 5 \\
\hline $3^{\mathrm{d}}(\mathrm{n}=10)$ & $138.92 \pm 17.8 *$ & $0.072 \pm 0.012 *$ & $25.38 \pm 1.52$ & $52.17 \pm 1.06 *$ \\
\hline $4^{\text {th }}(n=10)$ & $82.19 \pm 12.2 *$ & $0.157 \pm 0.038 *$ & $28.17 \pm 1.74$ & $66.15 \pm 1.38$ \\
\hline \multicolumn{5}{|c|}{ Spleen } \\
\hline $1^{\mathrm{st}}(\mathrm{n}=10)$ & $8.21 \pm 1.54$ & $0.458 \pm 0.007$ & $15.18 \pm 0.98$ & $17.53 \pm 1.91$ \\
\hline $2^{\text {nd }}(n=10)$ & $8.27 \pm 1.75$ & $0.453 \pm 0.006$ & $14.01 \pm 0.67$ & $17.72 \pm 1.67$ \\
\hline $3^{d}(n=10)$ & $42.03 \pm 5.06 *$ & $0.553 \pm 0.007^{*}$ & $22.06 \pm 1.12^{*}$ & $16.07 \pm 1.38$ \\
\hline $4^{\text {th }}(n=10)$ & $35.62 \pm 3.10^{*}$ & $0.658 \pm 0.006$ & $24.31 \pm 1.35 *$ & $37.12 \pm 0.53$ \\
\hline \multicolumn{5}{|l|}{ Source: Author } \\
\hline Notes: ${ }^{*} \mathrm{p}<0.0$ & e $1^{\text {st }}$ group (cc & Jroun) $* * n<0$ & the $3^{\text {rd }}$ group & \\
\hline
\end{tabular}

Under the influence of sufan in animals, injected with rubomycin hydrochloride for 5 weeks, the level of CP was increased by 2.2 times; the activity of CPK was increased by $35 \%$ in comparison with animals that had been administered only with adriamycin only (refer to Table 1). In those animals administered with a combination of adriamycin and sufan, the level of glycogen in myocardium was increased by 2.1 times; the level of oxidized forms of nicotinamide coenzymes was increased by $21 \%$; the ratio of oxidized/reduced forms was increased by $30.3 \%$ in comparison with rats that had been administered the only with anthracycline antibiotic (see Table 1). The adenine nucleotides' system also had miminal effect in animals administered with a combination of adriamycin and sufan. Thus, the level of ATP was increased by 54\%, the level of ADP was increased by $40.5 \%$; the amount of AMP was decreased by $25 \%$ (refer to Table 3). During the adriamycin-induced intoxication, Sufan 
decreases the amount of TBA-active products and slightly increases the level of the reduced form of glutathione in myocardium and brain; the influence of sufan on the activity of the glutathione cycle enzymes was not considerable (refer to Table 4). Thus, under the influence of sufan in myocardium, the content of CP reduced forms of nicotinamide coenzymes and the general amount of adenines' system compounds were normalized; other parameters of energy metabolism and oxidative homeostasis were not completely normalized, but they were much closer to control values.

Consequently, in case of adriamycin-induced intoxication, it was revealed that the energy metabolism was disturbed. The level of oxidized forms and the total amount of nicotinamide coenzymes, $\mathrm{CP}$, glycogen, the ratio of oxidized/reduced forms, the amount of ATP and ADP were decreased; meanwhile, the level of NAD-hydrolase, the ADP/ATP ratio and the amount of inorganic phosphate were increased. Also, it was determined that the activation of LPO is sensitive to the action of adriamycin rats organs (myocardium, brain, and spleen). As for glutathione system, it is exhausted due to the anthracyclin LPO-activation, due to the reduced level of glutathione in myocardium and spleen and the decreased level of glutathione peroxidase activity in myocardium and brain, and the compensatory increase of glutathione reductase in myocardium and spleen. So, glutathione system is a sensitive link in the xenobiotics metabolism that is confirmed by experimental data (Tyunov \& Ivanova, 1988).

The pro-oxidative anthracyclin properties play a certain role in the realization of its pharmacological action (Bulkina, 1991). Thus, the mechanism of the antibiotic antitumor action is associated with the induction of the single-strand breaks in DNA, stimulated by free radicals that are formed during the adriamycin biotransformation in the hepatic microsomes, in the presence of NADPH (Bogush \& Sitdikova, 1984). Free radicals activate the process of LPO. It should be noted that the oxidative homeostasis changes, in case of adriamycin-induced intoxication, are very similar to those that can be obtained during the radiation damage, coinciding with the experimental data concerning the radiosensibilization action of adriamycin (Riabchenko, Smoryzanova, \& Dedenkov, 1981).

The use of sufan in combination with the IM antibiotic administration showed certain protective effects. These effects concerned the vast majority of energy metabolism indicators and the content of TBA-active products of glutathione system. The cardio-protective effect of sufan may be due to the fact that this substance is a derivative of succinic acid; it can be included in the Krebs cycle, thus increasing the heart energy potential. Besides the succinic acid possibility to create the high-level energy-rich compounds, it also has a property to improve the reduction of pyridine nucleotides, thus stimulating the cell regenerative processes. So, the adriamycin-induced intoxication causes significant disturbance of the energy metabolism and the pro-oxidative-anti-oxidative homeostasis in myocardium. The deterioration of the oxidative homeostasis in brain and spleen has the same tendency, but it is more considerable. The use of sufan decreases these metabolic manifestations of the toxic tissue affection. Thus, we conclude that the use of sufan is promising as a substance that corrects not only the hemodynamic parameters, but also the structural and metabolic deterioration, as a result of anthracycline-induced intoxication in myocardium and other organs.

\section{Conclusion}

The anthracycline-induced intoxication in rats was experimentally created via IM adriamycin administration at a dosage of $5 \mathrm{mg} / \mathrm{kg}$ per week for 5 weeks. This intoxication was characterized by the energy metabolism deterioration in myocardial tissues: the decrease of oxidized forms, the total amount of nicotinamide coenzymes, CP, glycogen, ratio of oxidized/reduced forms, and the amount of ATP and ADP; at the same time, the increase of NAD-hydrolase's activity, the ADP/ATP ratio, and the amount of inorganic phosphate. It was also characterized by the LPO activation in tissues of myocardial, brain, and spleen. The IM administration of sufan, at a dosage of $35 \mathrm{mg} / \mathrm{kg}$ during the 
adriamycin-induced intoxication, reduces the severity of energy metabolism and oxidative homeostasis disorders in myocardium, brain, and spleen.

\section{References}

Baraboj, V. A., Orel, V. E., \& Karnaukh, I. M. (1991). Peroksidatsia lipidov i radiatsia [Lipid peroxidation and radiation]. Kiev, Ukraine: Scientific Thought.

Bogush, T. A., \& Sitdikova, S. M. (1984). Monooksidazi pecheni i farmakodinamika karminomitsina i rubomitsina [The spleen mono oxygenase and the carminomycin and rubomycin pharmacodynamics]. Antibiotics, 29(6), 446-450.

Bulkina, S. P. (1991). Protivoopuholevie preparati: spravochnik [Antitumor drugs: catalog]. Kiev, Ukraine: Scientific Thought.

Chekman, I. S. (1980). Trudnosti farmakoterapii [The complication of pharmacotherapy]. Kiev, Ukraine: The Health.

Chekman, I. S., Guduvok, J. S., \& Gorchakova, N. O. (1994).Vliyanie ne-glikozidnoy strukturi kardiotonicheskogo preparata sufana na serdce [The influence of non-glycoside structure cardiotonic drug sufan on the heart]. The Drugs, 5-6, 36-41.

Kruglikova, G. O., \& Shtutman, C. M. (1976). Aktivnost glutation peroksidazi i glutation reduktazi na pechen kris posle injekciy natriya selenata [Glutathione peroxidase and glutathione reductase activity of rat's liver after the sodium selenite injection]. Ukrainian Journal of Biochemistry, 68(2), p. 223-228.

Nizhenkovska, I. V., Chekman, I. S., \& Pisarev, O. A. (1996). Vliyanie kardiotonicheskih preparatov na strukturu miokarda v sluchae ribomitsin-indutsirovanoy serdechnoy nedostatochnosty [The influence of cardiotonic drugs on the myocardium structure in case of rubomycin-induced heart failure]. Visnik Pharmacii, 3-4, 118-120.

Prokorova, M. I. (1982). Metody biohimicheskih issledovaniy (metabolism lipidov i energii): Konsultacia [The methods of biochemical investigations (lipid and energetic metabolism): Tutorial]. Leningrad, Russia: Leningrad University Publishing.

Riabchenko, N. I., Smoryzanova, O. A. \& Dedenkov, A. N. (1991). Radiosensibiliziruejee deystvie rubomicina i ego kompleksa s DNK [The DNA radiation sensibilization under the rubomycin influence and its complex]. Medical Radiology, 26(7), 46-50.

Saprikina, E. V., \& Salnik, B. U. (1988). Rol narushenia lipidnogo metabolizma v mehanizmah gepatotoksicheskih effektov rubomitsina [The role of lipid metabolism deterioration in the mechanism of hepatotoxical effects of rubomycin]. Antibiotics and Chemical Therapy, 23(6), 452-455.

Stukov, A. N., Myronyuk, T. N., \& Konkov, S. A. (1998). Protivoopuholevay aktivnost i toksichnost doksorubicina [The antitumor activity and toxicity of the doxorubicin]. Oncology Questions, 44(1), 100-102.

Tyunov, L. A., \& Ivanova, V. A. (1998). The role of glutathione in the processes of detoxification. Bulletin of AMS, USSR, 1, 62-69.

Volchehorskyy, I. A., Nalimov, A. G., \& Jarovinskij, B. G. (1989). Sopostovlenie razlichnih metodov opredelenia k produktam lipidnoy peroksidatsii v geptano-izopropanolovih ekstraktah krovi [The comparison of different methods of the lipid peroxidation products determination in heptane-isopropanol extracts of blood]. The Questions of Medical Chemistry, 35(1), 127-131. 